\title{
ЕКОНОМІКА
}

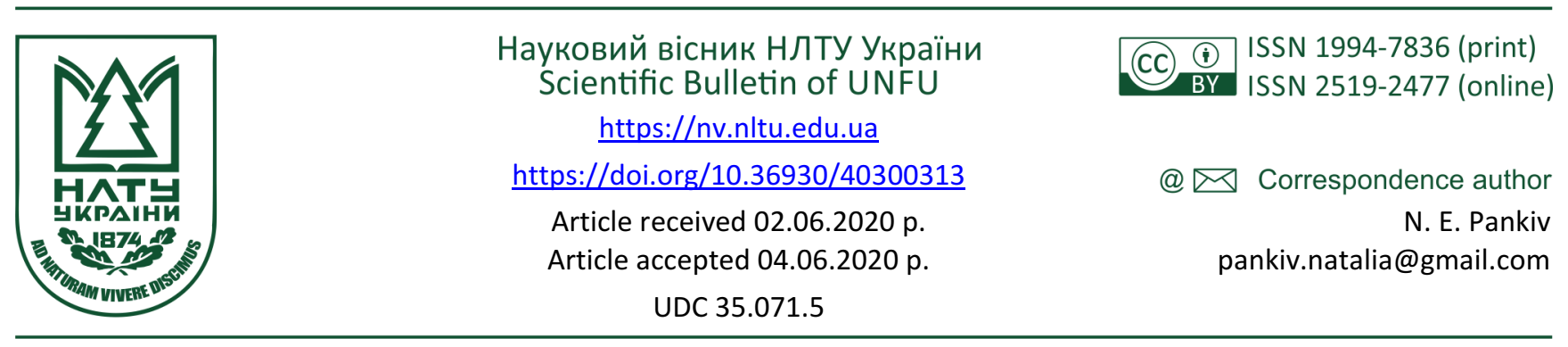

Н. Є. Паньків

Національний університет "Львівська політехніка", м. Львів, Україна

\section{СОЦІАЛЬНО-ЕКОЛОГІЧНИЙ ПІДХІД ДО РОЗРОБЛЕННЯ СТРАТЕГІЇ СТАЛОГО РОЗВИТКУ ТУРИЗМУ ТЕРИТОРІАЛЬНИХ ГРОМАД}

На прикладі запланованої Старосамбірської об'єднаної територіальної громади (ОТГ) Львівської області проаналізовано найвідоміші теоретичні моделі, побудовані на підставі соціально-екологічного підходу розвитку суспільства, призначених для застосування під час розроблення стратегії сталого розвитку територій. Встановлено, що соціально-екологічний підхід до розроблення стратегії сталого розвитку туризму територіальних громад, стане тим інноваційним механізмом, за допомогою якого регіон зможе реалізувати свій туристичний потенціал, базуючись на концепції сталого розвитку, що грунтується на двох основоположних підходах: ощадливе використання природних ресурсів та мінімізація шкоди для довкілля; забезпечення збалансованого соціально-економічного розвитку туристичних регіонів. Висвітлено проблеми та перспективи використання соціально-екологічного підходу до розроблення стратегії сталого розвитку туризму територіальних громад (на прикладі запланованої Старосамбірської об'єднаної територіальної громади Львівської області) та впровадження стратегічних планів економічного та соціального розвитку туризму об'єднаних територіальних громад для забезпечення високого рівня та якості життя населення регіонів України, створення сприятливих умов для діяльності нинішнього та майбутніх поколінь та припинення деградації природних екосистем шляхом впровадження нової моделі економічного зростання, що грунтується на засадах сталого розвитку. Встановлено, що пріоритетними напрямками розвитку туристичної сфери цього району є такі види туризму: сакральний; паломницький; ностальгійний; культурно-пізнавальний; рекреаційний; активний туризм, зокрема, піший туризм, велотуризм та екстремальний туризм та екологічний туризм. Саме стійкий попит на такий продукт сприятиме розвитку інфраструктури, малого та середнього підприємництва тощо. Результати досліджень наявних туристично-рекреаційних ресурсів, з урахуванням екологічної та соціально-економічної складових для реалізації принципів сталого розвитку громади $є$ важливими, як власне для окремих об'єднаних територіальних громад, так і для держави загалом.

Ключові слова: концепція сталого розвитку; стратегічне планування регіонального розвитку; соціально-економічний розвиток; пріоритетні напрямки туристичної сфери.

\section{Вступ}

Метою розроблення стратегії сталого розвитку туризму об'єднаних територіальних громад $є$ потреба істотного покращення умов та якості життя населення регіонів України, забезпечення сприятливих умов для діяльності теперішнього та майбутніх поколінь і припинення руйнування навколишнього природного середовища шляхом імплементації нової моделі економічного зростання, що базується на засадах сталого розвитку. Досягнення цієї мети відповідає світоглядним цінностям і культурним традиціям українського народу та міжнародним зобов'язанням України [13]. 3 ратифікацією Угоди про асоціацію між Україною та СС нашою державою було прийнято Стратегію сталого розвитку "Україна - 2030", якою передбачено низку секторальних реформи, серед яких чільне місце займає децентралізація та реформа державного управління [1].

Тому, на сьогодні, особливо актуальною є проблематика стратегічного планування регіонального розвит- ку в Україні, зважаючи на децентралізацію влади та реформу державного управління. Ці заходи передбачають передання повноважень і відповідних фінансових ресурсів для розвитку територій на місцевий рівень, чим i зумовлена потребу удосконалення методології та інструментарію стратегічного планування як на національному, так і на локальному рівнях. Адаптація регіональних економічних систем до нових умов та можливостей, пов'язаних 3 поглибленням євроінтеграційних процесів, потребує певного часу. Разом з тим лібералізація зовнішньоекономічної діяльності, зменшення бар'єрної функції кордону, безвізовий режим між Україною та ЄС тощо в перспективі здійснюватимуть відчутний вплив на екологічну ситуацію та соціальноекономічний розвиток регіонів, особливо прикордонних (Волинської, Львівської, Закарпатської, Івано-Франківської та Чернівецької областей), які мають спільний державний кордон з країнами-членами СС.

\section{Інформація про автора:}

Паньків Наталія Євгенівна, канд. біол. наук, доцент, кафедра туризму. Email: pankiv.natalia@gmail.com

Цитування за ДстУ: Паньків Н. Є. Соціально-екологічний підхід до розроблення стратегії сталого розвитку туризму територіальних громад. Науковий вісник НлтУ України. 2020, т. 30, № 3. С. 71-76.

Citation APA: Pankiv, N. E. (2020). Socio-ecological system approach to the development of a strategy for sustainable development of tourism of territorial communities. Scientific Bulletin of UNFU, 30(3), 71-76. https://doi.org/10.36930/40300313 
3 огляду на зазначене вище для дослідження було обрано Карпатський регіон, до складу якого входять чотири області Західної України - Львівська, Івано-Франківська, Закарпатська та Чернівецька. Особливістю процесів створення об'єднаних територіальних громад (ОТГ) у Карпатському регіоні $є$ наявність незначної кількості міських ОТГ та, зокрема, відсутність громад, утворених навколо міст обласного значення. Аналізуючи особливості формування та розвитку ОТГ Карпатського регіону, помітними $є$ порівняно вищі показники економічного розвитку та фінансової спроможності громад, центрами яких є міста. Серед ОТГ Карпатського регіону таких громад десять. Зараз, затверджено створення декількох таких громад у Карпатському регіоні. Зокрема, у Львівській області, Старосамбірському районі. На території району утворені три об'єднані територіальні громади (ОТГ): Міженецька ОТГ з центром у селі Міженець; Новоміська ОТГ з центром у селі Нове Місто; Нижанковицька ОТГ з центром у селищі міського типу Нижанковичі. У 2020 р. на території Старосамбірського району заплановано утворити чотири об'єднані територіальні громади: Старосамбірську, Добромильську, Хирівську та Стрілківську [12].

Об'єктом дослідження є стратегія сталого розвитку туризму територіальних громад Карпатського регіону.

Предметом дослідження є методи і засоби побудови соціально-екологічного підходу до розроблення стратегії сталого розвитку туризму територіальних громад (на прикладі запланованої Старосамбірської об'єднаної територіальної громади Львівської області).

Мета дослідження полягає в обгрунтуванні соціально-екологічного підходу до розроблення стратегії сталого розвитку туризму територіальних громад, що стане тим інноваційним механізмом, за допомогою якого регіон зможе реалізувати свій туристичний потенціал, базуючись на концепції сталого розвитку.

Завдання дослідження полягають в аналізі адміністративного устрою, кількості населення та якості життя Старосамбірської ОТГ; наявних туристично-рекреаційних ресурсів території та сучасного стану туристичної інфраструктури Старосамбірської ОТГ; виділенні ключових особливостей розвитку туризму на Старосамбірщині та пріоритетних напрямків туристичної сфери ОТГ і формуванні стратегічних завдань подальшого розвитку туризму, врахувавши його екологічну та соціально-економічну складові для реалізації принципів сталого розвитку громади.

Наукова новизна роботи полягає у тому, що вперше застосовано соціально-екологічний підхід до розроблення стратегії сталого розвитку туризму територіальних громад, за допомогою якого регіон зможе реалізувати свій туристичний потенціал, базуючись на концепції сталого розвитку, що грунтується на двох основоположних підходах: ощадливому використанні природних ресурсів та мінімізації шкоди для довкілля; забезпечення збалансованого соціально-економічного розвитку туристичних регіонів [7]. Окрім цього, розроблення ефективної регіональної політики щодо впровадження елементів сталого розвитку туризму відповідає пріоритетам Рамкової Конвенції про охорону та сталий розвиток Карпат [9].

Практична значущість отриманих результатів полягає у тому, що впровадження стратегічних планів економічного та соціального розвитку важливі як влас- не для окремих територіальних одиниць, так і для держави загалом. Тому основні положення результатів дослідження можна буде імплементувати на Стратегії розвитку областей Карпатського регіону стосовно близької та тривалої перспективи, що будуть базуватись на принципах сталого розвитку.

Матеріали і методи дослідження. У процесі дослідження застосовували аналітичний, порівняльно-географічний методи, а також методи узагальнення та систематизації.

Аналіз літературних джерел. Соціально-екологічний підхід було започатковано у 20-30-ті роки XX ст. у рамках Чикагської соціологічної школи (Р. Парк, Э. Берджесс, Р. Маккензі та ін.) [6]. Найвідомішими теоретичними моделями, що збудовані на підставі соціально-екологічного підходу, є концепція "екологічного співтовариства" А. Хоулі [3] та концепція "екологічного комплексу" О. Дункана і Л. Шноре. Основним завданням соціально-екологічного підходу $є$ аналіз функціонування людської популяції в екосистемі людини.

Наступною окремою галуззю психології, яка сформувалась під впливом екологічного підходу, стала $n c u$ хологія навколишнього середовища. Різниця між екологічним підходом та психологією навколишнього середовища полягає в тому, що для першого характерно розглядати взаємодію людини зі середовищем як перемінну, яку обов'язково необхідно враховувати під час аналізу різних проблем, психологія навколишнього середовища же зробила цю взаємодію предметом власних досліджень (Р. Баркера, С. Троубридж, Э. Толмен, К. Болдуін та ін.) [5]. На початку 90-х років у психологічній науці почала формуватися екологічна психологія, яка зросла на підставі екологічного підходу, але була орієнтована на дослідження саме екологічної свідомості. У психологічній конфесії виникло усвідомлення того, що екологічну кризу неможливо подолати без зміни панівної екологічної свідомості, що вона $є$ іiі "психологічною базою".

3 огляду на це постає питання розроблення таких методологічних основ, які дали б змогу вивчити психічні процеси, стани, поведінку і свідомість людини в їх природний єдності з погляду динамічних змін та розвитку системи "Людина-Природа" [6]. Отже, настав час ідей та дій, які мають виходити із цілісної концепції світорозуміння та відповідальності перед майбутніми поколіннями. Термін "сталий розвиток" (у перекладі $з$ англійської "sustainable development") за міжнародним стандартом 180 26000:2010 означає "життєздатний, раціональний розвиток" [4]. Його суть містить виклики щодо захисту довкілля, соціальної справедливості, боротьби з расовою і національною дискримінацією. Це такий розвиток суспільства, за якого задоволення потреб у природних ресурсах теперішнього покоління не має ставити під загрозу можливості майбутніх поколінь, передбачає узгодження екологічних, економічних і соціальних потреб.

Вирішенню низки зазначених вище проблем регіону, зокрема, зайнятість місцевого населення, будівництво шляхів сполучення та споруд житлового призначення, налагодження різних видів комунікацій, створення позитивного іміджу регіону, підтримка та розвиток місцевої культури, збереження навколишнього середовища сприяє розвиток туризму на конкретній теpumopiï. 3 огляду на це важливе значення мають дослі- 
джень туристичних ресурсів, як основи туристичної діяльності.

Карпатський регіон - надзвичайно мальовничий оздоровчо-рекреаційний природний об'єкт, відомий та популярний не тільки в Україні. Це ділянка $з$ цінними лісовими масивами, яка забезпечує регулювання водо- $\mathrm{i}$ повітряноочисної систем для європейських країн. Однак для Карпатського регіону характерна ціла низка світових проблем, зокрема, екологічні, соціальні та економічні проблеми. Тому дуже важливим завданням сьогодення $€$ застосування для розвитку туризму нових концепцій, які будуть базуватись на гармонізації співіснування людини та природи, на збереженні природних ресурсів, що використовуються для розвитку туризму та екологізації загальної свідомості людства. Одним 3 нових напрямків розвитку туризму є застосування засадничих принципів концепції сталого розвитку [2].

Стратегічним напрямом розвитку економіки Карпатського регіону проголошено туристично-рекреаційну галузь, яка є істотним показником стабільного й динамічного зростання надходжень до бюджету та позитивного впливу на покращення показників у багатьох галузях економіки. Оскільки регіон має спільні кордони i транспортне сполучення 3 Молдовою, Румунією, Угорщиною, Словаччиною, Польщею, то дослідження рекреаційно-туристичних ресурсів Карпатського регіону та тенденцій їх використання для сталого розвитку туризму сприятиме розвитку як внутрішнього, так і в"їзного туризму.

3 огляду на зазначене вище, тема дослідження є надзвичайно актуальною.

\section{Результати дослідження та їх обговорення}

Відповідно до проекту Перспективного плану об'єднаних територіальних громад на території Львівщини буде створено 72 ОТГ. У Старосамбірському районі заплановано утворити чотири об'єднані територіальні громади: Старосамбірську, Добромильську, Хирівську та Стрілківську.

Адміністративний устрій Старосамбірськой ОТГ. До складу Старосамбірської ОТГ 3 адміністративним центром у місті Старий Самбір увійдуть одинадцять громад: Старосамбірська, Старосолянська, Білицька, Великолінинська, Великосільська, Волошинівська, Волянська, Страшевицька, Стрільбицька, Тершівська, Торчиновицька. Територія компактна, найвіддаленіший населений пункт від центру ОТГ - міста Старий Самбір - знаходиться на відстані 20 км - с. Тиха. ОТГ розташована у південно-західній частині Львівської області, за 92 км від Львова, на перетині доріг, які ведуть до міст Львова та Ужгорода і митного перетину "СмільницяКросцєнко". Через місто проходить державна траса Н13 у напрямі Ужгорода та Львова [10].

Населення територіальної громади. Чисельність населення Старосамбірської ОТГ - 21910 осіб, зокрема дітей: 3252, дошкільного віку - 1232, шкільного віку 2020. Найчисельнішим пунктом є місто Старий Самбір, села Стрільбичі, Велика Лінина, Біличі, Страшевичі та смт Стара Сіль - понад тисяча наявного населення. Серед населення ОТГ 22,7 \% становлять міські жителі та 77,3 \% - сільські мешканці. Варто зазначити, що з кожним роком знижується ріст народжуваності. Окрім цього, інтенсивна міграція здебільшого молодого населення із сільської місцевості у міста та за кордон теж призвела до відповідної деформації вікової структури сільського населення - старіння населення. У Старосамбірській ОТГ є дитяча смертність. Отже, демографічна ситуація, що склалася впродовж останніх років, характеризується здебільшого негативними процесами - низькою народжуваністю, високим рівнем смертності, старінням та еміграцією населення [10].

Якість життя мешканиів території. Аналізуючи якість життя у ОТГ, варто зосередити увагу на двох ключових аспектах: по-перше, це переваги та недоліки проживання у районі, по-друге, це доходи населення району та його структурування за цим показником. Перевагами проживання є: оплата "гірських" працівникам бюджетних сфер; чисте природне середовище; у перспективі - розповсюдження на мешканців всього району Угоди про місцевий прикордонний рух; порівняно невисокий рівень злочинності; достатньо розвинений рівень фінансових і соціальних послуг; радше позитивний суспільний клімат. Варто також зазначити низку недоліків проживання на Старосамбірщині: відсутність необхідної інфраструктури; непривабливе, хаотичне планування територій під забудову через відсутність генеральних планів забудови; руйнація унікальних пам'яток матеріальної культурної спадщини; незадовільний ринок товарів, побутових і культурних послуг; алкоголізм, соціальне сирітство як наслідок нелегальної трудової міграції.

Клімат території - атлантико-континентальний. Він характеризується низьким тиском, високою вологістю повітря, а також прохолодним літом. Середньорічна температура $-7,5^{\circ} \mathrm{C}$, найпрохолодніші січень i лютий, а найтепліші - липень і серпень, пізні весняні заморозки бувають у червні, ранньоосінні - у серпні. Середня кількість опадів коливається у межах 800 мм. Такі умови сприяють утворенню аномальних природних явищ (повені та паводки, сніговали та вітровали, ожеледі та снігові заноси, поверхнева та глибинна ерозії земель та ін.).

Географічне розташування ОТГ умовно ділить ії на дві зони - передгірську та гірську (найбільшу за розмірами). Воно ж і визначає можливості господарювання у районі. Так, якщо у рівнинній зоні одним із пріоритетів розвитку, зважаючи на сприятливі умови, $є$ сільське господарство, то у гірській зоні основними перспективами розвитку є туризм та рекреація.

Корисні копалини території. Надра району багаті на різноманітні корисні копалини. Переважають серед них поклади кухонної солі, зокрема, біля смт Стара Сіль, які в сучасних умовах не розробляються. $Є$ тут будівельні та вогнетривкі глини, щебінь та нафта. Поширені ресурси представлені глинами, піском, галькою, каменем, вапняком, трапляються незначні запаси торфу. Особливим багатством району є великі запаси лікувальних мінеральних вод, які зовсім не використовуються, у смт Стара Сіль є принаймні чотири джерела 3 мінеральною водою. До прикладу, в урочищах Папрочизна і Верхола є мінеральна вода типу трускавецької "Нафтусі".

Автошляхи території. Довжина автомобільних доріг району становить 222,3 км, зокрема: 105,44 км - дороги 3 асфальтобетонним покриттям; 89,9 км - дороги iз гравійним покриттям; 27 км - грунтові дороги. Загальна довжина доріг державного значення, що проходить через район, становить 35,4 км, територіальних доріг - 70,6 км. На території розташовані 83 мости, біль- 
шість 3 яких у незадовільному технічному стані. Основними проблемами розвитку дорожнього господарства є: проблема власності дорожньої комунікаційної мережі; технічний стан доріг; потреба в інвестиціях на розвиток дорожнього господарства.

Зв'язок з мешканиями території. Варто також зазначити, що понад 80 \% території району покрито стільниковим зв'язком (оператори ЗАТ "Київстар Дж.Ес.Ем" та ЗАТ "МТС"). Проте села Воля та Кобло досі не мають покриття.

Функиіональними сферами ОТГ є: гірськолижні спуски у селах Сушиця; рекреаційні зони у місцевостях 3 наявними джерелами мінеральних вод - смт Стара Сіль; місця історичного та релігійного значення - історико-духовний комплекс у с. Лаврів, місце паломництва в с. Биличі; відпочинкові місця - аквапарк (Торчиновицьва сільська рада) тощо.

Однак туристична сфера Старосамбірського району наразі не сформована та практично не має шансу користуватися попитом, як серед внутрішніх, так і іноземних туристів. Незважаючи на високий лікувально-оздоровчий, пізнавально-естетичний та туристичний потенціал, а також вигідне географічне положення району, інфраструктура туристичної індустрії на Старосамбірщині розвинена недостатньо, потребує значних інвестицій та капіталовкладень.

Ключовими аспектами розвитку туризму на Старосамбіршині $\epsilon$ : абсолютно не сформований туристичний ринок у цій частині Прикарпаття (Старий Самбір, Турка, Великий Березний, Перечин); відсутність туристичного продукту; відсутність інфраструктури туристичної індустрії; слабка матеріально-технічна база туристичної сфери (готелі, мотелі, агротуристичні господарства); відсутність туристичних стежок при необмежених природних, історичних і культурних можливостях для їх створення; сприятливі природні умови для розвитку туризму; рекреаційний потенціал; наявність територій, придатних для розвитку гірськолижного туризму; наявність потенціалу для розвитку релігійного (пілігримного) туризму; наявність двох пунктів пропуску через державний кордон на території району, у перспективі будівництво ще трьох, що може забезпечити притік іноземних туристів [11].

У "Стратегії сталого розвитку Старосамбірського району до 2020 року" для розвиток туризму було передбачено реалізацію низки завдань, які залишаються актуальними і надалі: створення комплексної туристичної пропозиції району та ії̈ промоція; мобілізація потенціалу в сфері відпочинку; розвиток мережі туристичних маршрутів; розвиток об'єктів туризму та туристичних продуктів; реклама туристичного потенціалу району; сприяння розвитку лісової рекреації та туризму; сприяння розвитку мережі туристичних маршрутів, зокрема і транскордонних; будівництво, реконструкція або модернізація інфраструктури для збільшення використання природної спадщини в туризмі (наприклад, велосипедні доріжки, природні стежки і т.ін.), у т. ч. додаткової туристичної інфраструктури для полегшення використання природної спадщини (наприклад, велосипедні парковки, знакування, інфраструктура для людей 3 особливими потребами); сприяння розвитку агротуризму; розвиток інформаційно-промоційної діяльності туристичної привабливості району [13].

Пріоритетними напрямки туристичної сфери цього району с такі:
1) Сакральний - ознайомлення з пам'ятками сакрального мистецтва. Історичною пам'яткою райцентру $є$ церква Святого Миколая, яку збудовано у 1830 р. Сьогодні тут служать Богослужіння православні та греко-католицькі громади. Популярними серед туристів $є$ : дерев'яна Церква Різдва Пресвятої Богородиці (1620) у с. Велике. Василіанський монастир: церква св. Онуфрія (кінець XV ст.), монастирські приміщення (XV- поч. XX ст.), Лаврів. Костел св. Мартина (XVI-XVII ст.), с. Нове Місто. Комплекс церкви Різдва Пресвятої Богородиці: церква (XV-XVI ст.) 3 дерев'яною дзвіницею (XIX ст.), мури 3 брамою (XVIII-XIX ст.), Росохи. Костел св. Мартина 3 баштою-дзвіницею (XV-XVI ст.) і палац, с. Скелівка та інші.

2) Паломницький - це прощі у Биличі, Губичі, Лаврів і т.ін., хресна дорога у Губичах, Пастушкова церква.

3) Ностальгійний, мета якого - створення інформаційнопошукової бази і зацікавлення іноземців - вихідців із наших регіонів, повернення та відвідування ними місць народження, родинних осель, цвинтарів та ін.

4) Культурно-пізнавальний туризм. Серед основних ресурсів для його розвитку: Добромль $з$ його цікавими пам'ятками: ратуша (XVIII ст.), Василіянський монастир (XVIII ст.), Костел Преображення Господнього (XVI ст.), Замок Гербуртів (XVI ст.) на горі над містом, стіна пам'яті жертв Голокосту, вікові дерева - ясени, дуби та липи. Руїни та вали замку Мнішеків (за легендою, саме в ньому Джедмитрій I одружився з Мариною Мнішек), костел Непорочного Зачаття Пресвятої Діви Марії і св. мученика Георгія (XVIII ст.), залишки італійського парку, алея вікових лип; с. Муроване. Оборонна церква Пресвятої Трійці (XVI ст.) і міська забудова XIX ст., смт Нижанковичі. Меморіал жертвам НКВС на місці масової страти 1941 р. в урочищі Саліна, біля с. Солянуватка. Колишнє містечко Стара Сіль: бароковий костел св. Михаїла $(1660$ р.) 3 дзвіницею (XVII ст.), дерев'яна П'ятницька церква (1440р.) 3 дзвіницею (XVII ст.), вілла "Анна" (1911 р.) та інші цікаві споруди. Монастир кармелітів: костел св. Анни (15851591 рр.), монастирські келії (1608р.); с. Сусідовичі. Єзуїтська колегія або "конвікт" (XIX-хX ст.) і костел св. Лаврентія (XVIII ст.), м. Хирів. Дерев'яна дзвіниця церкви св. Михаїла (1730 рр.) з музеєм в середині; Ясениця-Замкова. Кіркут - давні єврейські поховання (XVI ст.), Старий Самбір (виїзд на Турку). Спаський або Чортів Камінь, скельний комплекс біля с. Бусовисько та інші.

5) Рекреаиійний, зокрема, з використанням наявних джерел мінеральних вод - смт Стара Сіль та ін.

6) Активний туризм: піший туризм (туристичні піші маршрути); велотуризм, зокрема, міжнародні велосипедні маршрути шлях R-63 (Бравого солдата Швейка) та шлях R-61 (Зелене коло); витяги, екстремальний туризм (рафтинг, альпінізм, лижний спорт, спортивнотуристичний пізнавальний захід "Левурда", який існує в районі уже 38 років).

7) Екологічний туризм - ознайомлення з флорою і фауною, характерною цьому регіону. На Старосамбірщині налічується 18 об'єктів та територій природно-заповідного фонду різних рангів і категорій заповідання загальною площею 8643,96 га, що становить 6,94\% від площі району, зокрема: 1 регіональний ландшафтний парк, 10 пам'яток природи, 4 заповідні урочища, 3 парки - пам'ятки садово-паркового мистецтва. У багатьох природоохоронних об'єктів (регіональний ландшафтний парк "Верхньодністровські Бескиди", пам'ятка садово-паркового мистецтва XVIII ст. загальнодержав- 
ного значення "Міженецький парк") існують передумови для розвитку широкого спектру форм екологічного туризму.

Як бачимо, Старосамбірський район має значний природно-рекреаційний та історико-культурний потенціал для розвитку туризму. Розташування Старосамбірського району, як прикордонної адміністративно-територіальної одиниці, повинно визначати пріоритети його розвитку. Можливостями, які зумовлені розташуванням району, повинні керуватися у визначенні цілей розвитку економіки, інфраструктури та туризму.

Уряд схвалив "Стратегію розвитку туризму та курортів на період до 2026 року", у документі зазначено таке: "Для популяризації туризму на регіональному рівні та з урахуванням ключових положень Стратегії розвитку туризму та курортів до 2026 року пропонуємо такі основні стратегічні завдання подальшого розвитку: 1) створення конкурентоспроможного регіонального туристичного продукту на засадах системної маркетингової діяльності, спрямованої на чітке позиціонування різних видів туристичних продуктів, адаптованих до вимог і очікувань споживачів; 2) забезпечення ефективного і комплексного (економічного, соціального, екологічного та інноваційного) використання наявного туристичного та курортно-рекреаційного потенціалу шляхом розв'язання проблеми рекреаційного природокористування та охорони навколишнього природного середовища та удосконалення територіальної структури сфери туризму та курортів з метою розвитку туристичних територій, брендингу територій; 3) системне підвищення якості інфраструктури рекреаційних територій шляхом виконання комплексної програми поетапного вдосконалення матеріально-технічної бази; 4) удосконалення інформаційної інфраструктури рекреаційних i туристичних послуг шляхом створення центрів туристичної інформації та популяризації туристичних продуктів під час провадження ярмаркової, фестивальної та виставкової діяльності; 5) забезпечення відповідності ціни та якості туристичних продуктів шляхом створення умов для оптимізації організаційно-економічної структури діяльності суб'єктів малого та середнього бізнесу у сфері туризму і розроблення національних стандартів надання туристичних послуг відповідно до міжнародних стандартів; 6) організація системи якісної підготовки, перепідготовки та підвищення кваліфікації фахівців туристичного супроводу та обслуговування, інших професій сфери туризму та курортів" [8].

\section{Висновки}

Отже, застосування соціально-екологічного підходу до розроблення стратегії сталого розвитку туризму територіальних громад (на прикладі запланованої Старосамбірської об'єднаної територіальної громади Львівської області) та механізмів контролю іiї виконання на рівні місцевої влади сприятиме розвитку туризму територіальних громад, стане тим інноваційним механізмом, за допомогою якого регіон зможе реалізувати свій туристичний потенціал, базуючись на концепції сталого розвитку.

Стратегічна мета перспективного розвитку територіальної громади буде базуватися на тому, щоб на підставі оптимального використання природних, матеріальнотехнічних, трудових і інтелектуальних ресурсів створити ефективну туристичну систему, яка забезпечить ма- теріальний добробут населення й екологічну безпеку, з урахуванням наявних у регіоні природного, економічного, наукового і технічного потенціалу, а також його історичних і географічних особливостей та туристичнорекреаційних ресурсів.

У цьому контексті важливе значення буде мати розроблення "Стратегії розвитку туризму Старосамбірської об'єднаної територіальної громади", засади якої можна буде імплементувати на Стратегії розвитку областей Карпатського регіону на близьку і тривалу перспективу, в основу яких повинні закладатися ідеї та принципи сталого розвитку.

\section{References}

1. Detsentralizatsiia v Ukraini ta yii vplyv na sotsialno-ekonomichnyi rozvytok terytorii: metodychni pidkhody ta rezultaty otsiniuvannia: naukova dopovid. (2018). (Doctor of Economic Sciences, prof. Storonianskyi, I. Z. Scientific Ed.). Lviv: IRD NANU, 144 s. (Seriia "Problemy rehionalnoho rozvytku"). Retrieved from: http://ird.gov.ua/irdp/p20180. [In Ukrainian].

2. Filep Diula. (2003). Ekoloho-ekonomichni zasady rozvytku prykordonnykh rehioniv Ukrainy ta Uhorshchyny. Abstract of Candidate Dissertation for Economic Sciences (08.10.01 - Location of productive forces and regional economy). Filep Diula, Lviv, 18 p. [In Ukrainian].

3. Hawley, A. (1968). Human ecology. International encyclopedia of the social sciences, 4, 328-337

4. ISO 26000:2010. Guidance on social responsibility. Retrieved from: http://isotc.iso.org.

5. Lapyn, E. A. (1991). Sovremennaia psykholohyia okruzhaiushchei sredy: sostoianye y perspektyvy. V kn.: Problemy jekolohycheskoi psykhoakustyky. Moscow, 51-76. [In Russian].

6. Morhunova, Ya. M. (2019). Analiz pidkhodiv do problemy "liudyna - pryroda" u zakhidnii psykholohii (Kyiv), In-t psykholohii im. H. S. Kostiuka APN Ukrainy. Retrieved from: http://www.ecopsy.com.ua/data. [In Ukrainian].

7. Pankiv, N. Ye. (2020). Kharakterystyka ekoturystychnoho potentsialu karpatskoho rehionu v konteksti staloho rozvytku turyzmu. Stalyi rozvytok - stan ta perspektyvy: Materialy II Mizhnarodnoho naukovoho sympoziumu SDEV2020 (12-15 liutoho 2020 roku, Lviv-Slavske, Ukraina), Lviv, 1 elektronnyi optychnyi dysk (DVD). 395-399. [In Ukrainian].

8. Pro skhvalennia Stratehii rozvytku turyzmu ta kurortiv na period do 2026 roku. (2020). Uriadovyi portal. Retrieved from: https://www.undp.org/content/ https://www.kmu.gov.ua/npas/249826501. [In Ukrainian].

9. Protokol pro stalyi turyzm. (2020). Ramkova konventsiia pro okhoronu ta stalyi rozvytok Karpat (Ofitsiinyi pereklad). Retrieved from: http://zakon1.rada.gov.ua/laws. [In Ukrainian].

10. Starosambirska OTH (perelik hromad). (2020). Staryi Sambir. Informatsiinyi portal mista. Retrieved from: http://p.starosambir.net.ua/?. [In Ukrainian].

11. Starosambirska RDA. (2020). Retrieved from: https://stsrda.gov.ua/starosa. [In Ukrainian].

12. Storonianska, I., Maksymenko, A., Levytska, O., Patytska, Kh., \& Siryk, Z. (2019). Sotsialno-ekonomichne stanovyshche obiednanykh terytorialnykh hromad: Zakhid VS Tsentr: naukovo-analitychne vydannia. NAN Ukrainy. DU "In-t rehionalnykh doslidzhen imeni M. I. Dolishnoho NAN Ukrainy". Lviv, 64 p. [In Ukrainian].

13. Stratehiia staloho rozvytku Starosambirskoho raionu do 2020 roku. (2018). Retrieved from: http://sts-rrada.gov.ua/wp-co. [In Ukrainian].

14. Stratehiia staloho rozvytku Ukrainy do 2030 roku. (2018). Proekt 2017. Retrieved from: https://www.undp.org/content/

15. Zinko, Yu., Malska, M., Ivanyk, M., \& Blahodyr, S. (2014). Turyzm u Karpatskomu rehioni: zahrozy dlia dovkillia ta sposoby staloho rozvytku. Bulletin of Lviv University. The series is geographical, 45, 443-451. [In Ukrainian]. 


\section{SOCIO-ECOLOGICAL SYSTEM APPROACH TO THE DEVELOPMENT OF A STRATEGY FOR SUSTAINABLE DEVELOPMENT OF TOURISM OF TERRITORIAL COMMUNITIES}

On the example of the planned stary sambir united territorial community of Lviv region the most well-known theoretical models based on the socio-ecological systemic approach to the development of society are analyzed in order to apply them during the development of a strategy for sustainable development of territories. It is defined that the socio-ecological system approach to the development of sustainable tourism strategy of territorial communities will be the innovative mechanism by which the region will be able to implement its tourism potential based on the concept of sustainable development based on 2 basic approaches: economical use of natural resources and minimization of damage to the environment; ensuring balanced socio-economic development of tourist regions. Problems and prospects of using a socio-ecological system approach to the development of sustainable tourism strategy of territorial communities (on the example of the planned Stary Sambir united territorial community of Lviv Region) and implementation of strategic plans of economic and social development of tourism of united territorial communities to ensure a high level and quality of life of the population of the regions of Ukraine, creation of favourable conditions for the activities of current and future generations and stopping the degradation of natural ecosystems by introducing a new model of economic growth based on the principles of sustainable development. The priority directions of development of the tourist sphere of this district are revealed to be the following types of tourism: sacred; pilgrimage; nostalgic; cultural and cognitive; recreational; active tourism, in particular hiking, cycling and extreme tourism and ecological tourism. It is the steady demand for such a product that will contribute to the development of infrastructure, small and medium enterprises, etc. The results of research of available tourist and recreational resources, considering environmental and socio-economic components for the implementation of the principles of sustainable community development are important, both for the individual united territorial communities and for the state as a whole.

Keywords: the concept of sustainable development; strategic planning of regional development; socio-economic development; priority areas of tourism. 